\title{
Tunability and Graded Energy Band Gap of Chemical Bath Deposited Cadmium Sulfide (CdS) Thin Film for Optoelectronic Applications
}

\author{
Sunday Samuel Oluyamo ${ }^{1}$, Abass Akande Faremi \\ ${ }^{1}$ Department of Physics, School of Sciences, The Federal University of Technology, Akure, Nigeria \\ ${ }^{2}$ Department of Physics, Federal University Oye-Ekiti, Oye-Ekiti, Nigeria
}

Email address:

abass.faremi@fuoye.edu.ng (A. A. Faremi)

\section{To cite this article:}

Sunday Samuel Oluyamo, Abass Akande Faremi. Tunability and Graded Energy Band Gap of Chemical Bath Deposited Cadmium Sulfide (CdS) Thin Film for Optoelectronic Applications. Nanoscience and Nanometrology. Vol. 6, No. 1, 2020, pp. 5-9.

doi: $10.11648 /$ j.nsnm.20200601.12

Received: July 30, 2019; Accepted: January 2, 2020; Published: January 16, 2020

\begin{abstract}
CdS thin films have continued to receive scientific and technological attention due to their potential applications in efficient solar energy conversion and utilization in device fabrication. In this research, CdS thin films were deposited on indium doped tin oxide (ITO) substrates of dimension 2.3 by $2.4 \mathrm{~cm}^{2}$. Three different aqueous bath solutions of CdS were formed by increasing the concentration of cadmium acetate as a source of cadmium while the concentration of ammonium chloride and thiourea as a source of sulfur remained constant in the reaction bath as against the usual convention to ascertain the strength of the constituents in the reaction. The energy band gap of the films decreases with increase in the concentration of cadmium as a constituent of the bath while the films optical transmittance was found to increase with increase in concentration. This indicates that the energy band gap of the films can be predetermined by the choice of the constituent of the concentration in the chemical bath deposition technique (CBD). The increase in the transmittance for both as deposited and annealed CdS confirms the suitability of the films as window layer device, solar cell and optoelectronic applications.
\end{abstract}

Keywords: Fabrication of CdS Thin Film, Chemical Bath, Thermal Treatment, Bang Gap Reengineering, Optical Properties

\section{Introduction}

Recently, the realization of interesting properties of group II, III, V and VI semiconductors such as wide band gap, high absorption coefficient, high chemical stability etc., have been attributed to the chemical solution-based synthesis route being a low cost and environmentally friendly fabrication techniques $[1-3,5]$. Several methods have been employed in the synthesis of compound semiconductor materials [4-9]. Chemical Bath Deposition (CBD) has received considerable attention due to its capability of adjusting and re-engineering semiconductor materials properties $[10,11]$. In this research work, chemical bath deposition was employed in the growth of Cadmium sulfide (CdS) thin film. CdS has gained a worldwide prominence due to its optical properties such as wide energy band gap $(2.45 \mathrm{eV})$, high transmission, good absorption coefficient [12] etc. It has also received tremendous attention because of its potential applications in efficient energy conversion from sunlight to electric energy $[13,14]$. The suitability of $\mathrm{CdS}$ for photovoltaic applications depend on the deposition parameters such as $\mathrm{pH}$, deposition temperature, duration of deposition and ionic concentration [15]. The potential of CdS thin film has been realized by the optimization of its preparative parameters [16, 17]. CdS has been known as the most promising heterojunction partner for prominent polycrystalline photovoltaic materials such as $\mathrm{CdTe}$ and $\mathrm{Cu}$ (In, Ga) $\mathrm{Se}_{2}$ [17]. Tremendous improvement has been made on cadmium telluride (CdTe) based solar cell when CdS is used as a window layer [18].

The formation of $\mathrm{CdS}$ requires optimized preparation 
techniques and CBD is known to meet this requirement [9]. Some major advantages of the formation of CdS compound semiconductor on the transparent conducting oxide (TCO) using CBD include proper adhesion. This results to free pinholes, fewer carrier trapping, chemical stability and high transparent layer capable of housing polycrystalline photovoltaic materials [19-22]. In this work, indium doped tin oxide (ITO) was employed as the substrate while the CdS thin films were obtained via the chemical bath deposition technique. The precipitation of CdS occurs when the ionic product is higher than solubility product [23]. In most of the previous researches on CdS, the source of sulfur $(\mathrm{S})$ often varies while the source of cadmium $(\mathrm{Cd})$ is kept constant [24]. The uniqueness of the present work is that the source of sulfur is kept constant while the source of cadmium is varied. The onus here is to ascertain the actual strength of the constituents in the reaction bath and their contribution in the adjustment of the properties of materials.

\section{Material and Method}

Chemical bath deposition technique was employed for the preparation of Cadmium sulfide (CdS) thin films. The reagents used for the preparation were analytical grade which include cadmium acetate (99\%), Thiourea (99.5\%) and ammonium chloride $(98 \%)$. The aqueous bath solution was prepared by dispensing $0.42 \mathrm{~g}$ of cadmium acetate $(\mathrm{Cd}$ $\left.\left(\mathrm{CH}_{3} \mathrm{COO}\right)_{2} .2 \mathrm{H}_{2} \mathrm{O}\right), 0.62 \mathrm{~g}$ of thiourea $\left(\mathrm{CS}\left(\mathrm{NH}_{3}\right)_{2}\right)$ and $1.4 \mathrm{~g}$ of ammonium chloride $\left(\mathrm{NH}_{4} \mathrm{Cl}\right)$ as a complexing agent into $500 \mathrm{ml}$ beaker contained $400 \mathrm{ml}$ of deionized water to produce $0.0045 \mathrm{M}$ of $\left.\mathrm{CH}_{3} \mathrm{COO}\right)_{2} .2 \mathrm{H}_{2} \mathrm{O}, 0.02 \mathrm{M}$ of $\mathrm{CS}\left(\mathrm{NH}_{3}\right)_{2}$ and $0.065 \mathrm{M}$ of $\mathrm{NH}_{4} \mathrm{Cl}$. The solution was magnetically stirred for 2 hours for the formation of homogeneous solution of the admixed solutes. The bath alkalinity was controlled to 9.0 using a $\mathrm{pH}$ meter and ammonium solution. Different samples of $\mathrm{CdS}$ were obtained by varying the concentration of $\mathrm{Cd}$ $\left.\left(\mathrm{CH}_{3} \mathrm{COO}\right)_{2} .2 \mathrm{H}_{2} \mathrm{O}\right)$. Three sets of samples were obtained with $0.0046,0.0097$ and $0.014 \mathrm{M}$ of $\left.\mathrm{Cd}\left(\mathrm{CH}_{3} \mathrm{COO}\right)_{2} .2 \mathrm{H}_{2} \mathrm{O}\right)$. The bath aqueous solution was heated up to a bath temperature of $90^{\circ} \mathrm{C}$ before the previously degreased substrate was immersed and deposition takes place. After the precipitation of CdS thin film on ITO substrate, the samples were immersed into deionized water for 10 minutes to remove the presence of chlorine and dried using hand dryer at $50^{\circ} \mathrm{C}$. The prepared samples were characterized for their morphological using scanning electron microscopy (SEM), elemental composition using energy dispersive x-ray spectroscopy (EDX) and optical properties using ultraviolet visible spectrophotometer (UV-vs).

\section{Results and Discussion}

\subsection{Morphological Properties}

The grain size and the shape of the deposited CdS as revealed by SEM were obtained through imagej analyzer to be $100 \pm 20 \mathrm{~nm}$ and round shape (columnar shape), respectively. The grains are uniformly distributed as shown in SEM micrograph (Figure 1). Nevertheless, little agglomeration of the grains is noticed in the films which could be due to the duration of deposition resulting to over growth of $\mathrm{CdS}$ nucleation and bath temperature. However, the film was more uniform and strongly adherent to the substrate when heat treated at a substrate temperature of $350^{\circ} \mathrm{C}$ in 20 minutes (Figure 1). This agrees with previous research [25-27].
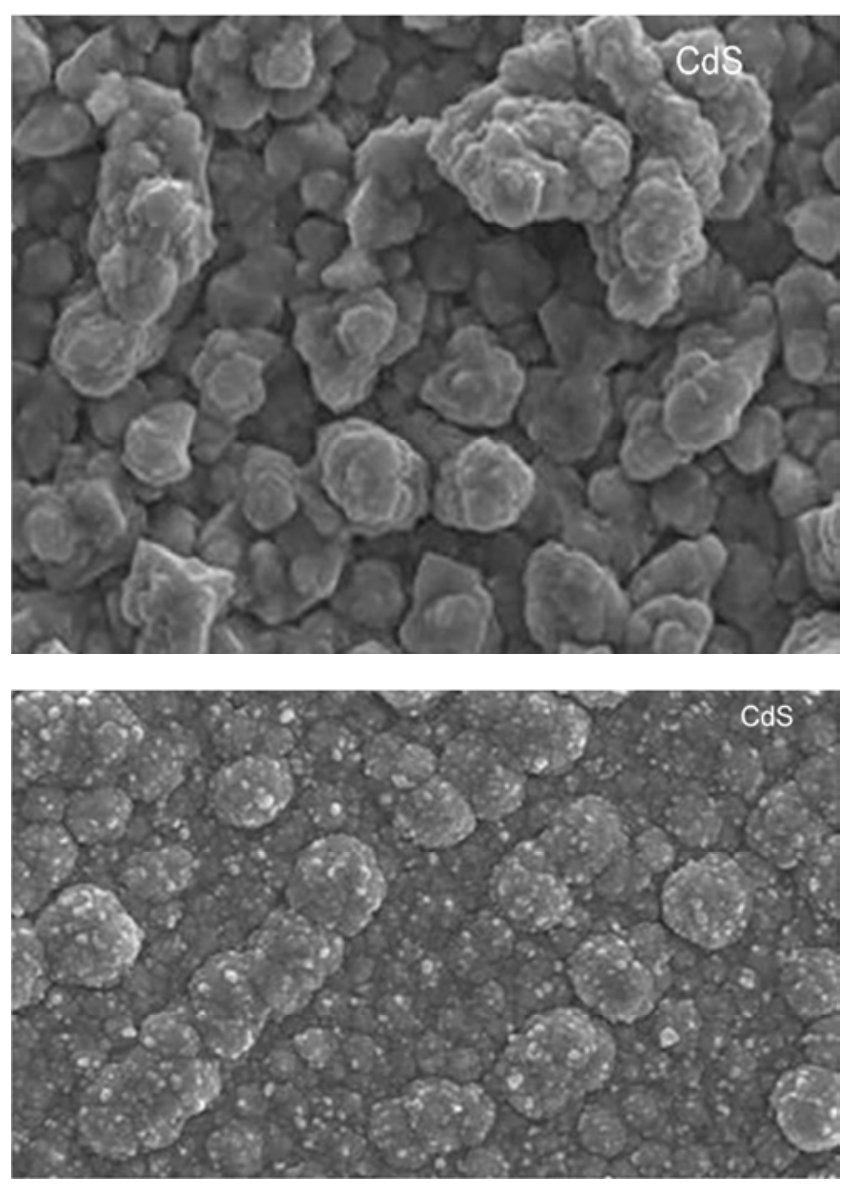

Figure 1. SEM for the CdS thin films deposited.

The EDX study revealed the presence of Cadmium (Cd), Sulfur (S) and indium (In) respectively. These elements were taking according to the $\mathrm{K} \alpha$ and $\mathrm{L} \alpha$ spectra energy levels. $\mathrm{Cd}$ has energy value of $\mathrm{L} \alpha=3.13 \mathrm{KeV}, \mathrm{S}$ has the energy value of $\mathrm{K} \alpha=2.307 \mathrm{KeV}$ and $\mathrm{In}$ has its value as $\mathrm{L} \alpha=3.207 \mathrm{KeV}$. However, the presence of indium as revealed by the EDX spectrum was not cleared but it could be suggested to have come from the substrate used. The quantitative atomic percentage of the compositional elements in CdS thin films are given as insert of Figure 2. It is important to note the presence of indium in the films as revealed in the EDX (Figure 2); Cd, S, being the primary constituents of the samples. In previous researches this peak had been constantly repeated as $\mathrm{Cd}$ probably due to the proximity of the energy value/atomic mass of In and $\mathrm{Cd}$. In addition, the substrate glass used in the research is made of indium. Hence the In indicated could have been injected into the film from the substrate. 


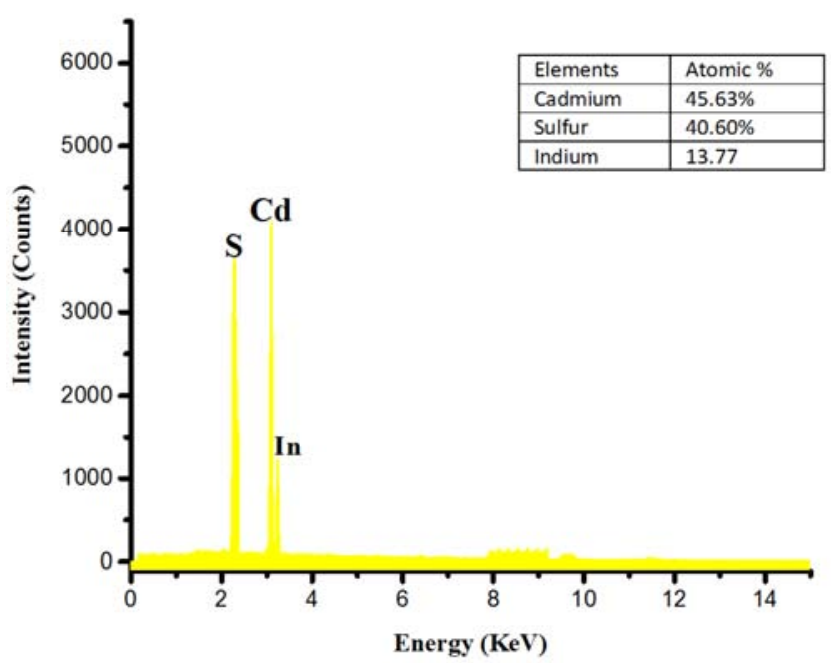

Figure 2. Energy dispersive $x$-ray analysis (EDX) of CdS thin films.

\subsection{Analysis of Energy Band Gap}

The energy band gap of the CdS thin films for both as deposited and heat-treated films as shown in Figures 3 and 4 were calculated by plotting $(\alpha h v)^{2}$ against $h v$. In this study, the energy band gap of $\mathrm{CdS}$ decreases as the concentration of cadmium acetate increases and also decreases when heat treated. CdS has been characterized with a direct energy band gap. The energy band gap was obtained from the interception of the straight line on the $h v$ axis as shown in the graph. This is achieved by extrapolating the linear portion of the graph. The plot of $(\alpha h v)^{2}$ against $h v$ as proposed by Tauc and Mott [28-29] was used to determine the energy band gap of the synthesized films

$$
\alpha h v=A\left(h v-E_{g}\right)^{n}
$$

where $\mathrm{A}$ is a constant usually unity, $\mathrm{E}_{\mathrm{g}}$ is the energy band gap and $\mathrm{n}$ is the transition between valence band and conduction band, $\mathrm{n}$ is equal to 0.5 and 2 for direct and indirect transitions respectively.

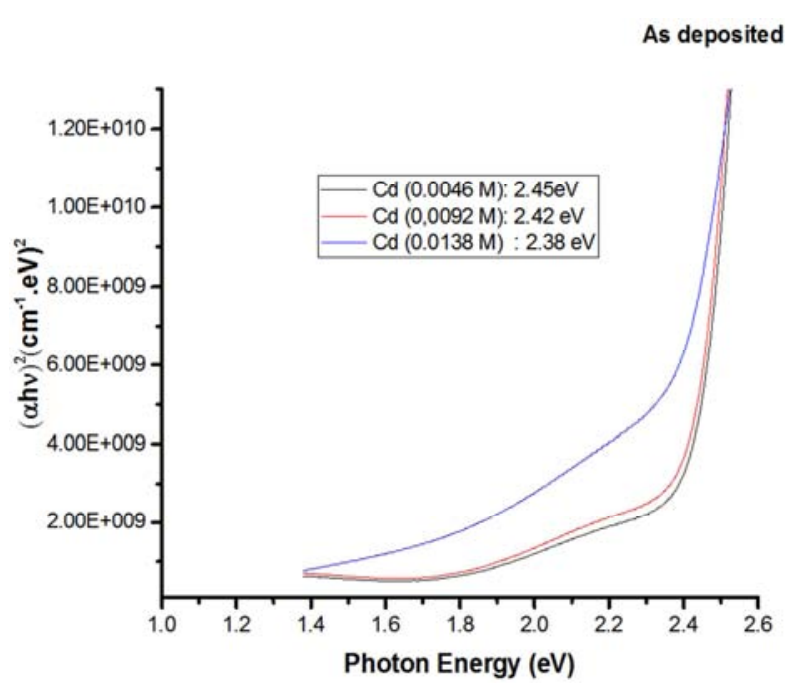

Figure 3. Comparison of energy band gap of as deposited CdS thin films via a chemical bath deposition with Cd molarity variation.

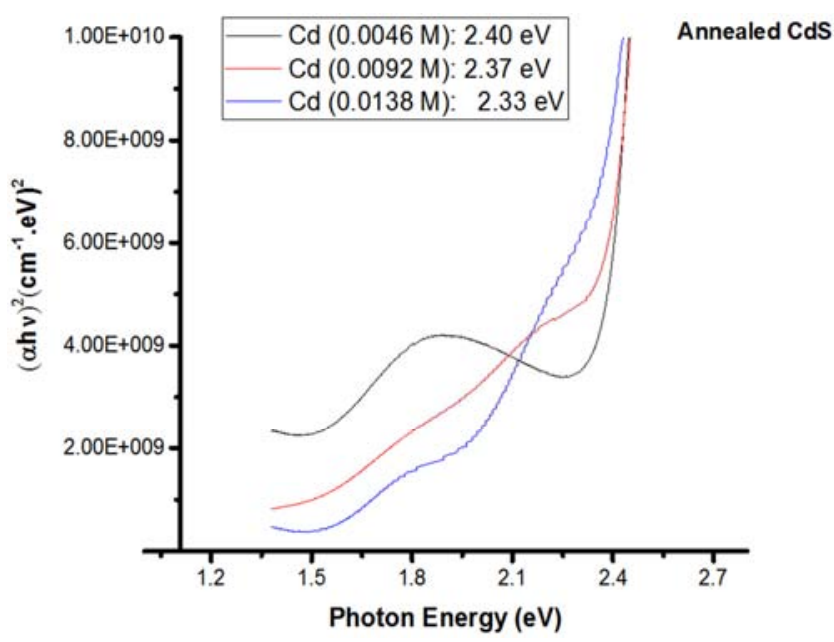

Figure 4. Comparison of energy band gap of heat-treated CdS thin films at substrate temperature of $350^{\circ} \mathrm{C}$ in 20 minutes via a chemical bath deposition with $\mathrm{Cd}$ molarity variation.

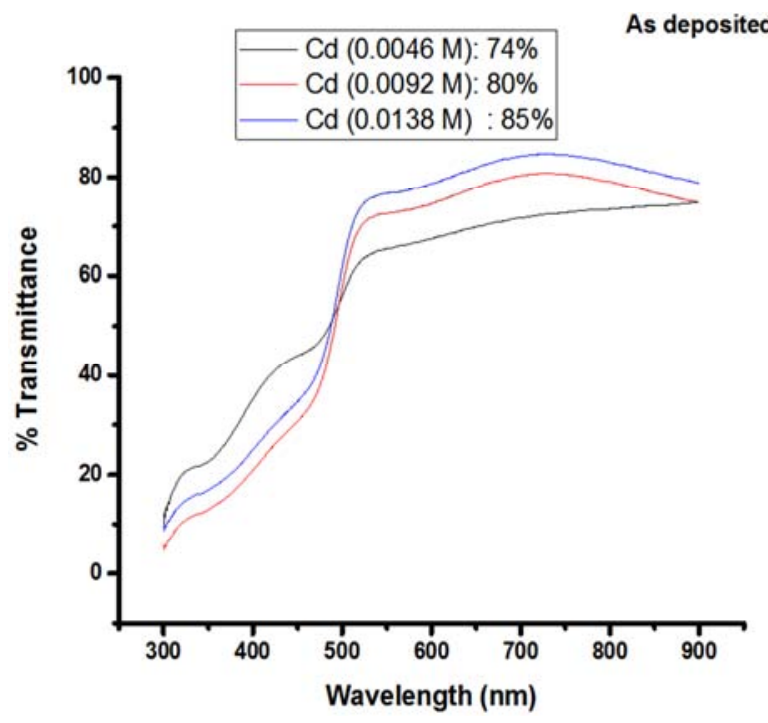

Figure 5. Comparison transmittance spectra percentage of as deposited CdS thin films via a chemical bath deposition with Cd molarity variation.

When a semiconductor material is heat-treated, the material's properties changes [29]. Evidence of this is noticed in the band gap of the heat-treated films. Similar phenomena have also been reported in previous researches [30-32]. Subsequent energy band gap was achieved as the concentration of $\mathrm{Cd}$ increases in the sample. Consequently, graded band gap energies of the films were achieved by successive and careful selection of $\mathrm{Cd}$ concentration in the fabrication of the material. Therefore, the utilization of CdS for solar and optoelectronic application can be tuned for specific functions.

The average transmittance of CdS films as shown (figures 5 and 6) increases with increase in $\mathrm{Cd}$ concentration and more pronounced when heat-treated. The usual decrease in the defect density due to the heating process could have favoured the improvement in the transmittance of the heattreated samples [29]. Improvement in the crystallinity of materials was noticed with heat treatment [33]. Such 
treatment in most cases heals worked samples and enhances the realignment of particles that are thrown off their lattice sites as a result of machining during fabrication. This phenomenon has been attributed in previous research on $\mathrm{CdS}$ as a result of surface irregularity and defect density [34]. Furthermore, the treatment of materials after fabrication at temperature is believed to promote recrystallization; nevertheless, at high temperature and long annealing duration, material loss becomes an important factor [29, 35]. The percentage of transmittance of as deposited and heattreated films is more pronounced above the wavelength of $500 \mathrm{~nm}$ and such behaviour has been reported previously as one of the prerequisites for optoelectronic devices, especially for solar cell window layers [36, 37]. Specifically, the increase in the percentage transmittance is noted to be rapid within the wavelength range of $350-550 \mathrm{~nm}$ as evidence in the spectrum (Figure 6). The occurrence of the transmittance is an evidence for the formation of dense films on the surface of the substrate $[38,39]$.

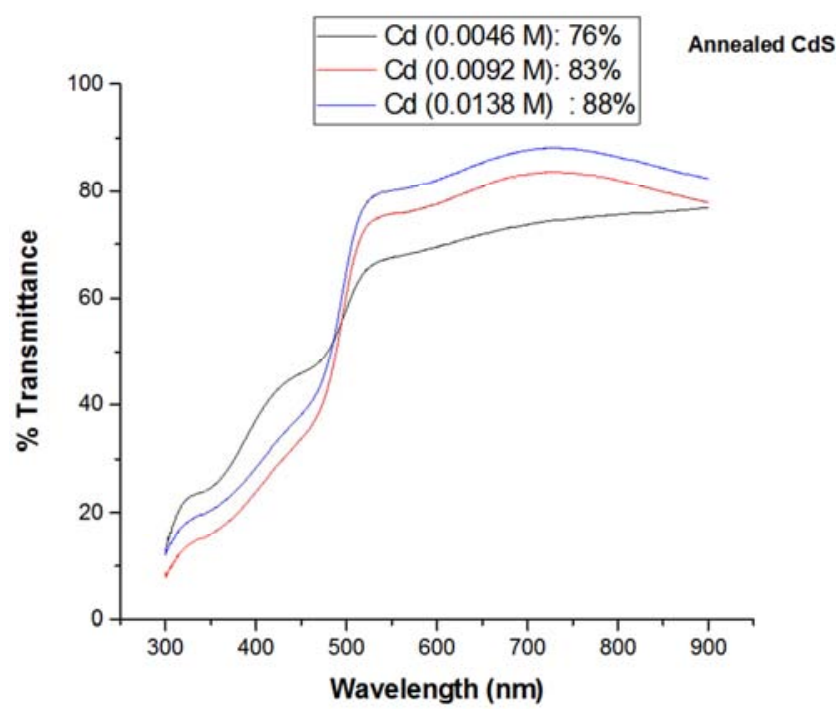

Figure 6. Comparison transmittance spectra of heat-treated CdS thin films at substrate temperature of $350^{\circ} \mathrm{C}$ in 20 minutes via a chemical bath deposition with Cd molarity variation.

\section{Conclusion}

In this work attempt had been made to deposit and synthesize $\mathrm{CdS}$ through $\mathrm{CBD}$ route with varied $\mathrm{Cd}$ concentration. The grain size and the shape of the film as obtained by SEM is an indication that the film was evenly distributed, and the elementary components of the film was revealed by EDX as Cd and $\mathrm{S}$. The ultraviolet visible spectrophotometer for the film optical properties, revealed that the thicker the film, the higher the band gap but the lesser upon heat treatment. Such changes in the optical band gap of nanostructured materials can be explained based on quantum size effect. The result revealed that graded energy band gap could be obtained for specific optoelectronic device applications. All CdS thin films deposited showed good transmission as the transmittance spectra increases with wavelength. The rapid increase in the transmission above
$500 \mathrm{~nm}$ revealed that the material showed potentials for good window layer for heterojunction solar cell and optoelectronic device applications.

\section{References}

[1] Alaa AA, Hassanien AS. Microstructure and crystal imperfections of nanosized CdSxSe1- $\mathrm{x}$ thermally evaporated thin films. Sup. latt. Microstruc. 2015; 85: 67-81. DOI: http;//dx.doi.org/10.1016/j.spmi. 2015, 0 5.011.

[2] N. R. Pavaskar, C. A. Menezes, and A. P. B. Sinha, 'Photoconductive CdS Films by a Chemical Bath Deposition Process' J. of Electrochem Soc. 124, 1977, pp 743-748.

[3] P. Niesen and M. R. De Guire, "Review: Deposition of Ceramic Thin Films at Low Temperatures from Aqueous Solutions," Journal of Electroceramics, Vol. 6, No. 3, 2001, pp. 169-207. doi: 10.1023/A:1011496429540.

[4] R. Grecu, E. J. Popovici, M. Ladar, L. Pascu, E. Indrea; 'Spectroscopic Characterization of Chemical Bath DepositedCadmium Sulfide Layers' Journal of Optoelectronics and Advanced Materials Vol. 6, No. 1, 2004, pp. 127-132.

[5] Mohd Norizam Md Daud, Azmi Zakaria, Atefeh Jafari, Wan Rafizah, and Zulkarnain Zainal. "Characterization of CdTe Films Deposited at Various Bath Temperatures and Concentrations Using Electrophoretic Deposition” Int. J. Mol. Sci. 2012, 13, 5706-5714; doi: 10.3390/ijms13055706.

[6] H. R. Moutinho, M. M. Al-Jassim, D. H. Levi, P. C. Dippo and L. L. Kazmerski, "Effect of $\mathrm{CdCl} 2$ Treatment on CdTe Thin Films," Journal of Vacuum Science \& Technology A, Vol. 16, No. 3, 1998, pp. 1251-1257. doi: 10.1116/1.581269.

[7] A. D. Compaan, A. Gupta, J. Drayton, S.-H. Lee and S. Wang, "14\% Sputtered Thin-Film Solar Cells Based on CdTe," Physica Status Solidi (b), Vol. 241, No. 3, 2004, pp. 779-782. doi: $10.1002 / p s s b .200304281$.

[8] Y. P. Chen, S. Sivananthan and J. P. Faurie, "Structure of CdTe(111)B Grown by MBE on Misoriented Si(001)," Journal of Electronic Materials, Vol. 22, No. 8, 1993, pp. 951-957. doi: 10.1007/BF02817509.

[9] M. C. Nuss, D. W. Kisker, P. R. Smith and T. E. Harvey, "Efficient Generation of 480 fs Electrical Pulses on Transmission-Lines by Photoconductive Switching in Metalorganic Chemical Vapor-Deposited CdTe," Applied Physics Letters, Vol. 54, No. 1, 1989, pp. 57-59. doi: 10.1063/1.100834.

[10] G. Hodes, "Chemical Solution Deposition of Semicon- doctor Films," Marcel Dekker Inc., New York, 2002, doi:10.1201/9780203909096.

[11] J. Han, C. Spanheimer, G. Haindl, G. Fu, V. Krishnakumar, J. Schaffner, C. Fan, K. Zhao, A. Klein and W. Jaegermann, "Optimized Chemical Bath Deposited CdS Layers for the Improvement of CdTe Solar Cells," Solar Energy Materials and Solar Cells, Vol. 95, No. 3, 2011, pp. 816-820. doi: 10.1016/j.solmat, 10.027 .

[12] Okike Okorie and Ramalan Abubakar. "Influence of Thickness on the Optical Properties of Cadmium Sulphide Thin Film Deposited by Chemical Bath Deposition Technique", 2017, DOI: 10.9734/PSIJ/2017/35738. 
[13] Chopra, K. L. and Das, S. R; "Thin film Solar Cells" Plenum Press, New York 1983.

[14] Ezema, F. I. Okeke, C. E. Greenwich J. Sci. Tech., 2003, 3 90109.

[15] Narayana Swamy T N, Pushpalatha H L, and Ganesha R. Chemically deposited CdS thin film and its photoelectric performance. J. Chem. Bio. Phy. Sci. Sec. C. 7 (1): 2017; 119130.

[16] Dilip Maske "Growth and Characterization of CdS Thin Films by Chemical Bath Deposition" International Journal of Scientific and Research Publications, Volume 6, 2016, ISSN 2250-3153.

[17] X. Wu, J. C. Keane, R. G. Dhere, C. DeHart, A. Duda, T. A. Gessert, S. Asher, D. H. Levi, P. Sheldon, Proc. 17th European Photovoltaic Solar Energy Conf. 2001, p. 995.

[18] M. Estela Calixto, M. L. Albor-Aguilera, M. TufiñoVelázquez, G. Contreras-Puente and A. Morales-Acevedo. "Chemical Bath Deposited CdS for CdTe and $\mathrm{Cu}(\mathrm{In}, \mathrm{Ga}) \mathrm{Se} 2$ Thin Film Solar Cells Processing” www.intechopen.com.

[19] D. Dwyer, R. Sun, H. Efstathiadis, P. Haldar, Characterization of chemical bath depositedbuffer layers for thin film solarcell applications, Phys. Status Solidi A 207 (10), 2010, 22722278.

[20] M. M. Islam, S. Ishizuka, A. Yamada, K. Sakurai, S. Niki, T. Sakurai, K. Akimoto, CIGS solar cell with MBE-grown ZnS buffer layer, Sol. Energy Mater. Sol. C 93, 2009, 970-972.

[21] M. A. Contreras, M. J. Romero, B. To, F. Hasoon, R. Noufi, S. Ward, K. Ramanathan, Optimization of CBD CdS process in high-efficiency $\mathrm{Cu}(\mathrm{In}, \mathrm{Ga}) \mathrm{Se} 2$-based solar cells, Thin Solid Films, 2002, 403-404 (204-211).

[22] Raghad Y, Mohammed S, Abduol, Ali M. Mousa. Structural and optical properties of chemically deposited CdS thin films. International Letters of Chemistry, Physics and Astronomy. 2014, 10: 91-104

[23] R. Mendoza-Pereza, G. Santana-Rodriguezc, J. SastreHernandeza, A. Morales-Acevedod.

[24] A. Arias-Carbajal, O. Vigil-Galan, J. C. Alonsoc, G. Contreras-Puente "Effects of thiourea concentration on CdS thin films grown by chemical bath deposition for CdTe solar cells" Thin Solid Films 480-481, 2005, 173-176.

[25] Chaki SH, DeshpandeMP and Tailor J P Thin Solid Films 550, 2014. 291-7.

[26] H. Khallaf, G. Chai, O. Lupan, L. Chow, S. Park, A. Schulte, Investigation of aluminium and indium in situ doping of chemical bath deposited CdS thin films, J. Phys. D: Appl. Phys. 41, 2008, 185304-185313.
[27] Ouachtari F, Rmili A, Elidrissi S E B, Bouaoud A, Erguig H, Elies P. Influence of bath temperature, deposition time and $[\mathrm{S}] /[\mathrm{Cd}]$ ratio on the structure, surface morphology, chemical composition and optical properties of $\mathrm{CdS}$ thin films elaborated by chemical bath deposition. J Mod Phy, 2011, 2: 1073-1082.

[28] Tauc J. Amorphous and Liquid Semiconductors, New York Plenum, 1974.

[29] Mott N. F, Davis E. A. Electronic Processes in NonCrystalline Materials Calendron Press Oxford 1979.

[30] J. Pantoja and Enriquez "Effect of Annealing time and temperature on Structural, Optical and Electrical Properties of CdS films deposited by CBD" Chalcogenide Letters, Vol. 10, No. 2, February 2013, p. 45-53.

[31] H Moualkia, S Hariech, MS Aida, N Attar and EL Laifa, Growth and physical properties of CdS thin films prepared by chemical bath deposition, J. Appl. Phys 42, 2009, 135404.

[32] S. S. Oluyamo and O. A. Abdulsalam "Optical, Electrical and Solid State Properties of Nano Crystalline Zinc Sulphide Thin Films for Device Applications" Nigeria Journal of Pure \& Applied Physics, Vol. 6, No. 1, 2015, pages 33-39.

[33] Ziaul Raza Khan, M. Zulfequar, Mohd. Shahid Khan. "Effect of Thickness on Structural and Optical Properties of Thermally Evaporated Cadmium Sulfide Polycrystalline Thin Films", Vol. 7, 2010, p. 431-438.

[34] M Ichimura, F Goto and E Arai, Structural and optical characterization of $\mathrm{CdS}$ films grown by photochemical deposition, J. Appl. Phys 85, 1999, 7411.

[35] A. Hasnat, and J. Podder "Effect of Annealing Temperature on Structural, Optical and Electrical Properties of Pure CdS Thin Films Deposited by Spray Pyrolysis Technique" Advances in Materials Physics and Chemistry, 2012, 2, 226-231 doi: 10.4236/ampc.2012.24034.

[36] S. A. Vanalakar, S. S. Mali, M. P. Suryavanshi and P. S. Patil, Dig. J. Nanomater. Bios. 5 2010, p. 805.

[37] J. Hiie, T. Dedova, V. Valdna, K. Muska, Thin Solid films, 2006, 443-511.

[38] Ayodeji Awodugba, Oluwaseun Adedokun and Y. K Sanusi Annealing Effect of Temperature on the Optical Properties of Nanostructure CdS Films Journal of Applied Physics, 2014, DOI: $10.9790 / 4861-06213439$.

[39] Ezema F. I, S. C. Ezugwu, R. U. Osuji, P. U. Asogwa, B. A. Ezekoye, A. B. C. Ekwealor, and M. P. Ogbu. "Role of Thermal Annealing on the Optical and Solid-State Properties of Chemically Deposited Cadmium Sulphide Nanocrystalline Thin Film Grown in a Polymer Matrix, Journal of Non-Oxide Glasses. 1 (1), 2010, 45-50. 